10 Packard RBS. Pattern of mortality in choroidal malignant melanoma. Br J Ophthalmol 1980; 64: 565-75.

11 Seddon JM. Albert DM. Lavin PT. Robinson N. A prognostic factor study of disease-free interval and survival following enucleation for uveal melanoma. Arch Ophthalmol 1983; 101: 1894-9.

12 Seddon JM, Gragoudas ES, Albert DM, Hsieh CC, Polivogianis L, Friedenberg GR. Comparison of survival rates for patients with uveal melanoma after treatment with proton beam irradiation or enucleation. Am J Ophthalmol 1985: 99: 282-90.

13 Augsburger JJ, Gamel JW. Sardi VF, Greenberg RA. Shields JA, Brady LW. Enucleation vs cobalt plaque radiotherapy for malignant melanomas of the choroid and ciliary body. Arch Ophthalmol 1986; 104: 655-61.

14 Gass JD. Comparison of prognosis after enucleation vs cobalt-60 irradiation of melanomas. Arch Ophthalmol 1985: 103: 916-23.

\section{Is irradiation a justifiable treatment of choroidal melanoma?}

SIR, In reply to the letter by Drs Char et al., the answer to the question, 'at what stage in the natural history of the disease must intervention occur to avoid development of metastasis,' is: at the earliest feasible one, preferably before the 7 $\mathrm{mm}$ diameter stage (see paragraphs 3 of previous replies). ${ }^{20}$ The answer on 'the most effective means of treating this tumour' is: enucleation at the earliest feasible stage; this eliminates any (further) dissemination. Irradiation of melanomas has been a regular practice for about 15-20 years. The reason that 'there are no definitive data that demonstrate that either irradiation or enucleation is superior in preventing tumour-related mortality' is the surprising lack of reported $\geqslant 10$-year survival results of irradiated patients. Only one clinic has published prospective 10-ycar comparative survival results of all primary enucleated and irradiated patients in the same period.'

So far 39 calculated doubling times of uveal melanomas have been reported. Paragraph 4 of our reply ${ }^{2}$ to Drs Zimmerman et al. ${ }^{3}$ explains why it is warranted to assume that nearly all metastatic deaths within $6 \cdot 1$ ycars after treatment are a consequence of pre-existing dissemination.

More than $50 \%$ of 153 microscopically studied irradiated melanomas did not reveal any necrosis, while $94 \%$ contained viable tumour tissue. ${ }^{+}$One wonders that ophthalmic radiotherapists, not being trained pathologists, claim to be able to interpret better the viability of melanoma cells, which presumably they have not studied, than trained patholegists who have studied these tumours. Charet al. state that they have not observed mitoses in some irradiated melanomas. Other pathologists and we have observed mitoses in proton beam and in ruthenium irradiated melanomas. Besides, a body is legally dead because of the presence of signs of death, not because vital signs are absent.

The findings by Gass in his 10-year follow-up of all patients have never been 'shown to be invalid'. The main criticism is the greater number of anteriorly located melanomas in the irradiation group. Many believe, for no reason, that anterior melanomas have a worse prognosis. Weinhaus et al. found that "patients with juxtapapillary melanomas had a worse prognosis than those with tumors in other locations'.
Our statement" "almost all survival statistics after irradiation are still based on follow-up periods of a few months to no more than three to four years' was correct at the time it was submitted (see paragraphs 7-9 of reply to Dr Oosterhuis et al. ${ }^{\top}$ ).

Our statement that 'patients have the right to be treated by enucleation which eliminates any further dissemination' is progressively becoming more supportable. Death from metastases, disseminated after irradiation, cannot manifest itself before six years after therapy. 'Short-term analyses' of treated patients are irrelevant. Survival rates after enucleation, irradiation, and observation are identical during the first six post-treatment years if the selection conditions have been identical. Results more than six years after irradiation have been published only twice; both were highly unfavourable. ${ }^{\text {s }}$

After enucleation any (further) dissemination is prevented. After irradiation major parts of the remaining tumour tissue (69\% after a two-year follow-up period") continue their growth and will shed cell emboli, eventually causing metastatic death after more than six years.

W A MANSCHOT

Erasmus University,

Rotterdam.

The Netherlands

\section{References}

1 Gass JD. Comparison of prognosis after enucleation vs cobalt-60 irradiation of melanomas. Arch Ophthalmol 1985: 103: 916-23.

2 Manschot WA, van Strik R. Reply. Br J Ophthalmol 1988; 72: 559-60).

3 Zimmerman LE, McLean JW. Irradiation and choroidal melanoma. Br J Ophthalmol 1988: 72: 558-9.

4 Manschot WA, van Strik R. In: Zografos L, ed. Updated analysis of published results of irradiation of uveal melanomas. Proc 2 nd international meeting on diagnosis and treatment of intraocular tumours. Nyon, Switzerland: 1987, in press.

5 Weinhaus RS, Seddon JM, Albert DM, Gragoudas ES, Robinson N. Prognostic factor study of survival after enucleation for juxtapapillary melanomas. Arch Ophthalmol 1985; 103: 1673-7.

6 Manschot WA, van Strik R. Reply. Br J Ophthalmol 1988; 72: 319.

7 Oosterhuis JA, Lommatzsch PK. Wessing A. Is irradiation a justifiable treatment of choroidal melanoma? $\mathrm{Br} J$ Ophthalmol 1988: 72: 317-9.

8 Davidorf FH, Pajka JT, Makley TA, Kartha MK. Radiotherapy for choroidal melanoma. An 18-year experience with radon. Arch Ophthalmol 1987; 105: 352-5.

9 Char DH, Saunders WM, Gragoudas WS. Charged particle (helium ion and proton) therapy. Ophthalmic Forum 1983; 1: $42-4$.

\section{Familial exudative vitreoretinopathy (FEVR) and platelet dysfunction}

SIR, Chaudhuri et al.' reported abnormal platelet aggregation in patients from two families with familial exudative vitreoretinopathy (FEVR). However, Gole et al. ${ }^{2}$ reported no platelet aggregation defects in a patient with incontinentia pigmenti, a separate syndrome with a phenotypically similar proliferative retinopathy. These two conflicting findings are at odds with regard to association between FEVR and platelet function. 